\title{
Actions of gonadotrophins on the uterus
}

\author{
Mordechai Shemesh \\ Department of Hormone Research, Kimron Veterinary Institute and Koret Veterinary School, \\ Hebrew University, Bet Dagan POB 12, Israel 50250
}

\begin{abstract}
Binding sites for $\mathrm{LH} / \mathrm{hCG}$ are found in the uterus of several species, including humans. In cattle and pigs, the $\mathrm{LH}$ receptor, its mRNA and $\mathrm{LH}$ receptor protein are present in the uterus throughout the oestrous cycle, and maximum expression occurs at the luteal phase. $\mathrm{GnRH}$ receptor is also expressed maximally in the human endometrium at the luteal phase. LH activates both the adenylate cyclase and phospholipase $\mathrm{C}$ pathways and increases the concentrations of cyclooxygenase and its products. Activation of LH receptors in the endometrium is associated with PGF production. In contrast, bovine uterine vein $\mathrm{LH}$ receptor mRNA and $\mathrm{LH}$ receptor concentrations are greatest during pro-oestrus-oestrus and LH increases the production of both PGE and PGF. FSH receptor and its mRNA are present in the bovine cervix and the concentrations are greatest at the time of the FSH peak value in the blood, indicating a physiological role for FSH in the relaxation and opening of the cervix. The presence of gonadotrophin and releasing factor receptors with a dynamic pattern in the endometrium, myometrium, oviduct and cervix of different species provides evidence that gonadotrophins and GnRH play a substantial role as molecular autocrine-paracrine regulators of the oestrous cycle and implantation.
\end{abstract}

The pituitary gonadotrophins, $\mathrm{LH}$ and $\mathrm{FSH}$, in addition to hCG, belong to the family of glycoprotein hormones consisting of two dissimilar noncovalently bound $\alpha$ and $\beta$ subunits (Pierce and Parsons, 1981). The $\beta$ subunits of hCG and LH are different from those of FSH. The $\beta$ subunits of LH and hCG are similar except for an additional 30 amino acids at the carboxy terminus of the $\beta$ subunit of hCG. These additional amino acids are responsible for the longer half-life of hCG in the circulation compared with that of LH.

The receptors (R) for both $\mathrm{LH}$ and FSH belong to a common gene family, the G-protein-associated seven-transmembrane domain receptors (Catt and Dufau, 1991). There is no specific receptor for hCG, which binds to the same receptor (LH-R) as pituitary $\mathrm{LH}$, with a somewhat higher affinity (Huhtaniemi and Catt, 1981).

The main physiological functions of the gonadotrophins are well known. LH stimulates production of androgens by theca cells in the ovary, providing a substrate for oestrogen production by granulosa cells, which triggers ovulation and provides luteotrophic activity to maintain the production of progesterone by the corpus luteum. hCG is also a luteotrophic hormone that maintains corpus luteal function until about week 9 of pregnancy, at which time the primary site of progesterone synthesis shifts to the placenta (Csapo et al., 1972). FSH stimulates follicular maturation and oestrogen production by granulosa cells in the ovary.

Email: mshem@vs.moag.gov.il
It has became apparent over the last decade that FSH and $\mathrm{LH}$, as well as $\mathrm{GnRH}$, affect organs other than their 'traditional' target sites. Receptors for the gonadotrophins have been found throughout the reproductive tract: in the oviduct, myometrium, endometrium, cervix and the uterine vessels. Receptors for $\mathrm{GnRH}$ have been found in the endometrium and trophoblast. Various paradigms have been proposed for the function of these receptors as their expression is dynamic and changes during the oestrous cycle.

The object of the present article is to review the current knowledge of extragonadal gonadotrophin receptors in the reproductive tract and to suggest the physiological functions of these receptors. It will focus on the bovine and porcine reproductive tracts, as these have been the most extensively studied, and compare data with relevant published studies in other species.

\section{Extragonadal receptors in the reproductive tract}

\section{Endometrium}

Expression and activity of $\mathrm{LH}$ receptor and GnRH receptor. In the human endometrium, LH-R and GnRH-R are expressed in both epithelial and stromal cells and both receptors are expressed maximally during the luteal phase (Reshef et al., 1990; Raga et al., 1998). Comparison of immunostaining intensities revealed that human luminal and glandular epithelial cells contain more receptors than stromal, myometrial or vascular smooth muscle cells. 


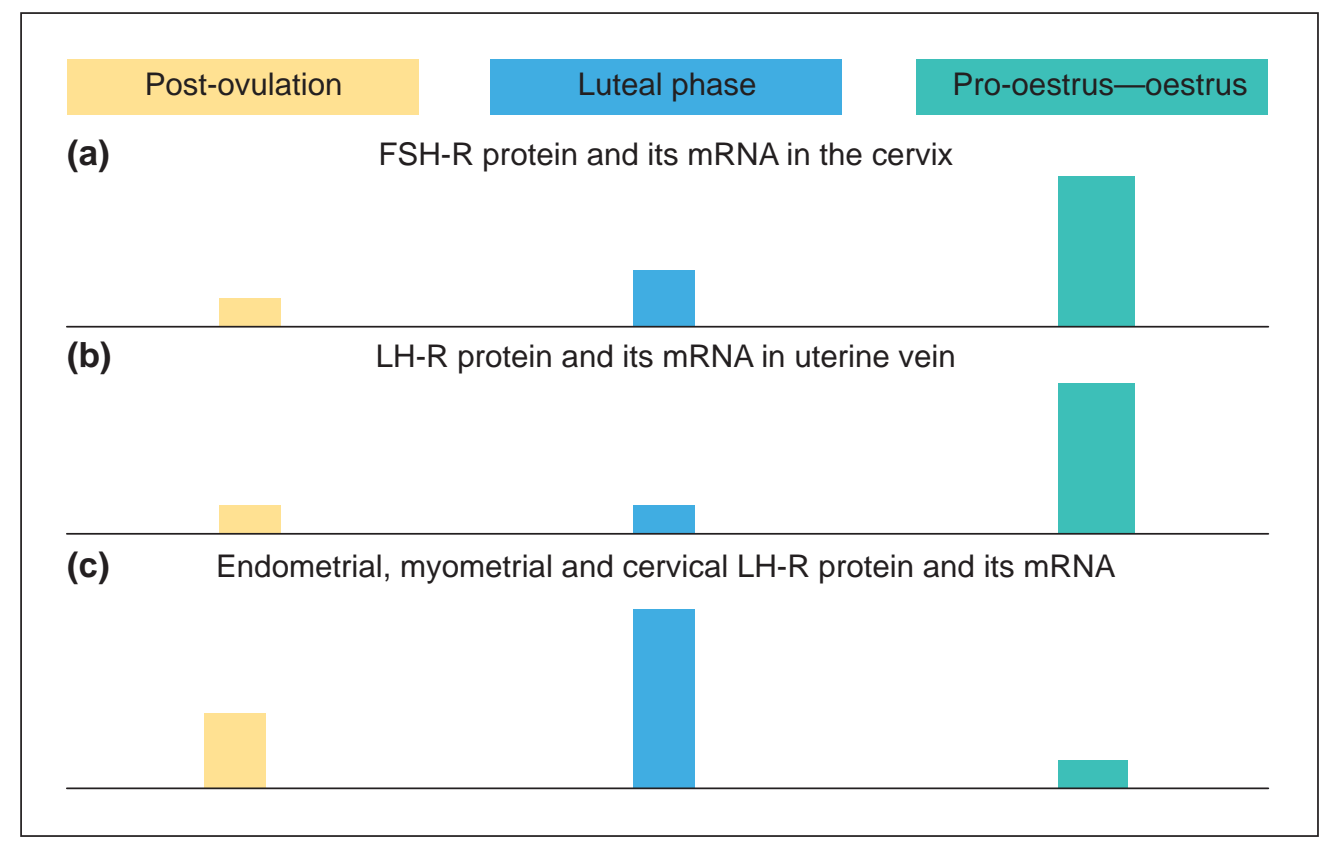

Fig. 1. Schematic presentation of the expression of uterine gonadotrophin receptors. Relative concentrations of $\mathrm{LH}$ and FSH receptors $(\mathrm{R})$ and their mRNA expression throughout the oestrous cycle are depicted. LH-R protein and its mRNA are expressed maximally in the endometrium, myometrium and cervix in the late luteal phase whereas, in the uterine veins, LH-R and its mRNA are expressed maximally at pro-oestrus-oestrus. In contrast, FSH-R protein and its mRNA are expressed maximally at pro-oestrus-oestrus. This scheme is primarily representative of the bovine uterus, but appears to be valid for the pig and human uterus also.

In cattle, LH-R and its mRNA expression were greatest during the luteal phase but there was expression after ovulation as well (Fig. 1C). LH induced a rapid increase in endometrial cAMP and inositol phosphate $\left(\mathrm{IP}_{1}, \mathrm{IP}_{2}\right.$ and $\left.\mathrm{IP}_{3}\right)$ production (Mizrachi and Shemesh, 1999a). Increased amounts of second messenger were associated with increased concentrations of endometrial cyclooxygenase (COX-2) and its metabolite PGF. The size of the LH-R protein on SDS gels appeared to be the same $(93 \mathrm{kDa})$ in all of the bovine reproductive tract tissues tested, and similar to that found in the rat ovary (Rodriguez and Segaloff, 1990). The pattern of LH-R expression appears to be similar in pigs (Ziecik et al., 1986, 1992a, 2000) (Fig. 1).

Physiological role of $\mathrm{GnRH}$. The presence of a dynamic pattern of expression of $\mathrm{GnRH}$ and its receptor in both the epithelium and stroma of the human endometrium provides evidence that this hormone plays a substantial role as a molecular autocrine-paracrine regulator in embryoendometrial interactions during early implantation. Furthermore, in women, injection of $\mathrm{GnRH}$ agonist enhances implantation (for references, see Raga et al., 1998) through an increase in trophoblastic hCG release.

Physiological role of $\mathrm{LH}$ receptor. The actions of $\mathrm{LH}$ on the endometrium, which reach a maximum during the luteal phase, are apparently unrelated to the ovulatory LH peak value that occurs several days later. This finding indicates that novel intracellular factors may be involved in the regulation of the oestrous cycle in ruminants and implantation in women. There is a direct temporal relationship among the increased concentration of $\mathrm{LH}$ receptors, induction of COX-2 and PGF production in endometrial epithelial cells (Shemesh et al., 1994; Friedman et al., 1995; Stepien et al., 1999; Fig. 2), implying a role for LH in the initiation of bovine and porcine luteolysis. However, after the initiation of luteolytic endometrial PGF secretion, the number of LH/hCG receptors declines, indicating that PGF depletes endometrial gonadotrophin binding sites at the follicular stage of the oestrous cycle. This concept is supported by the results of studies showing that injection of PGF induces a rapid inhibition of bovine corpus luteal progesterone production and then a decreased concentration of luteal LH/hCG binding sites (Behrman, 1979). Although the extragonadal actions of $\mathrm{LH}$ do not correspond to the ovulatory peak values of $\mathrm{LH}$, Rahe et al. (1980) have shown that there are pulses of $\mathrm{LH}$ even in the luteal phase. Furthermore, the increased expression of the LH-R in the uterus may be more important than the concentration of $\mathrm{LH}$ in the plasma.

In the endometrium, there is an apparent dichotomy in the concept that LH is involved in uterine PGF synthesis 
since LH (appropriately named for its luteotrophic action) is known to drive progesterone synthesis by the corpus luteum. Furthermore, the role of endometrial $\mathrm{LH}$ in luteal regression, if any, has not been documented.

The physiological significance of LH/hCG binding sites and PGF production during the postovulatory phase of the oestrous cycle is not known. Secretion of PGF at this early stage of the cycle may be necessary for the movement of the early embryo from the Fallopian tube to the uterus. Ziecik et al. (2000) have proposed that LH may also stimulate endometrial COX-2 and PG synthesis during the early stages of pregnancy. However, the presence of the blastocyst probably acts to alter the final product such that the primary PG released is PGE rather than PGF (Weems et al., 1993; Danet-Desmoyers et al., 1994).

LH may also act through CAMP to regulate progesterone synthesis and its metabolism, as hCG does in the rat uterus (Bonnamy et al., 1989). Two possible target enzymes in the uterus are $5 \alpha$-reductase (progesterone to $5 \alpha$-pregnandione) (Thatcher et al., 1983) and aromatase. An increase in uterine aromatase activity may explain why plasma oestradiol concentrations in the pro-oestrous uterine vein are much higher than peripheral values.

LH binding to receptors during the luteal and postovulatory phases might affect many systems, since $\mathrm{LH}$ dependent cAMP or calcium second messenger systems activate a variety of enzymes. Therefore, the induction of COX-2 by LH may represent just one of several enzymes induced by $\mathrm{LH}$ to regulate the oestrous cycle and pregnancy. Furthermore, a more complete understanding of the precise mechanism regulating the concentration of LH/hCG binding sites in early pregnancy would have to include its relationship with interferon $\tau$.

The stimulatory effect of $\mathrm{LH}$ on uterine COX-2 and its associated product PGF observed in vitro was also demonstrated in vivo using hCG (Canino et al., 1999). When cows were injected with 3000 iu hCG on day 15 of the oestrous cycle, the concentration of 13,14-dihydro-15keto $\mathrm{PGF}_{2 \alpha}$ (PGFM; a metabolite of $\mathrm{PGF}_{2 \alpha}$ ) was greater than that of cows injected with either saline or oxytocin. Similar results were found in ovariectomized cows implanted with progesterone.

\section{Myometrium}

Expression of $L H$ receptor and activity of $L H$. Specific, high-affinity, low-capacity binding sites for LH/hCG were first reported in the pig myometrium (Ziecik et al., 1986, $1992 a, b)$. LH-R is also present in the myometrial muscle of women (Reshef et al., 1990), rats (Bonnamy et al., 1990; Sawitzke and Odell, 1991), rabbits (Jensen and Odell, 1988) and cows (Shemesh et al., 2001). In all of the species studied, expression of LH-R is dependent on the stage of the cycle. Expression of LH-R and its mRNA is high during the luteal phase but they are expressed only weakly during the follicular phase (Fig. 1c). LH activates both the cAMP and phospholipase $\mathrm{C}$ pathways and the effect of $\mathrm{LH}$ on

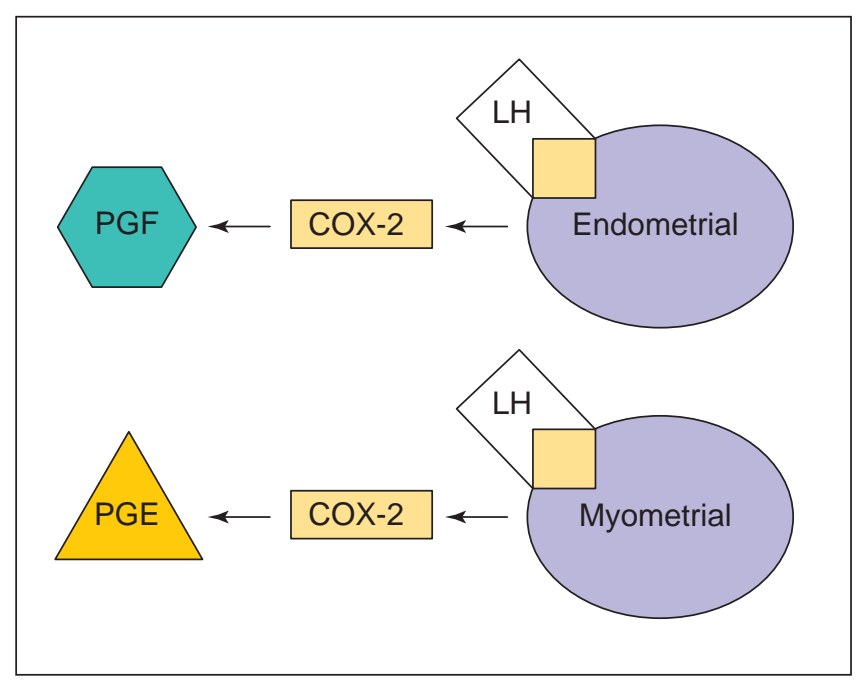

Fig. 2. Schematic presentation of LH-stimulated uterine cyclooxygenase (COX)-2 and its products, PGE and PGF, at the luteal phase. Under LH stimulation, the principal product of COX-2 is PGF in the endometrium and PGE in the myometrium. This scheme is primarily representative of the bovine uterus, but appears to be valid for the pig uterus also.

both pathways at each stage of the cycle is correlated with the amount of LH-R present in the tissue. Activation of these signalling pathways is associated with an increase in the expression of cyclooxygenase and production of $\mathrm{PGE}_{2}$ in the bovine myometrium (Fig. 2).

Physiological role of $\mathrm{LH}$ receptor. $\mathrm{LH}$ receptor may have a role in the hyperplasic hypertrophy of the uterus and uterine motility (for a review, see Ziecik et al., 1992a), consistent with a decrease of intracellular calcium concentrations in human myometrial smooth muscle cells after hCG treatment. Myometrial growth and uterine relaxation seen during early pregnancy may be regulated in part by trophoblastic hCG in women or pituitary LH in pigs or other non-primates. High concentrations of LH-R induced by oestradiol allow a relaxing effect on the pig myometrium, which is not seen in the absence of LH-R (Flowers et al., 1991). Therefore, regulation of $\mathrm{LH}-\mathrm{R}$ resulting in increased binding of $\mathrm{LH}$ and an increase in CAMP may serve to maintain the quiescence of the uterus during the luteal phase.

\section{Uterine artery and vein: expression of $L H$ receptor and activity of $L H$}

Human uterine and umbilical arteries, but not placental vessels, contain hCG receptors (Rodway and Rao, 1995). In the human uterine artery, hCG was found to stimulate $\mathrm{PGI}_{2}$ and $\mathrm{PGF}_{2 \alpha}$ but decrease production of $\mathrm{PGE}_{2}$ and thromboxane $A_{2}$. In cows, LH-R and its mRNA are expressed maximally at pro-oestrus-oestrus (Fig. 1) and LH increases COX-2 and its products in the uterine vein maximally during pro-oestrous-oestrus (Shemesh et al., 1997). 


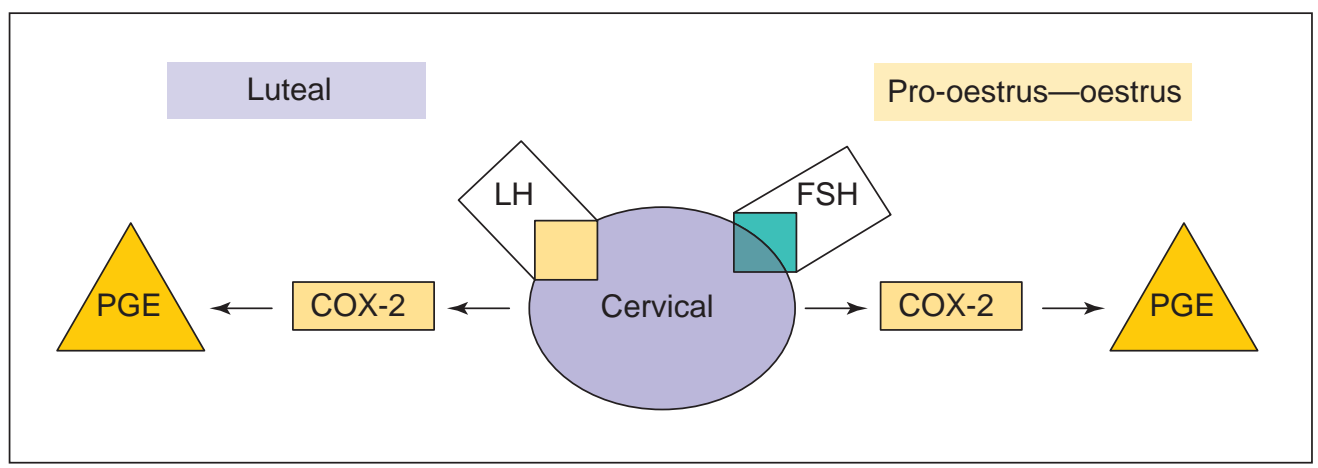

Fig. 3. Schematic presentation of the stimulatory effect of LH and FSH on cervical PGE production. The cervical cells were most responsive to $\mathrm{LH}$ at the luteal phase and to $\mathrm{FSH}$ at pro-oestrus-oestrus. COX-2: cyclooxygenase 2 .

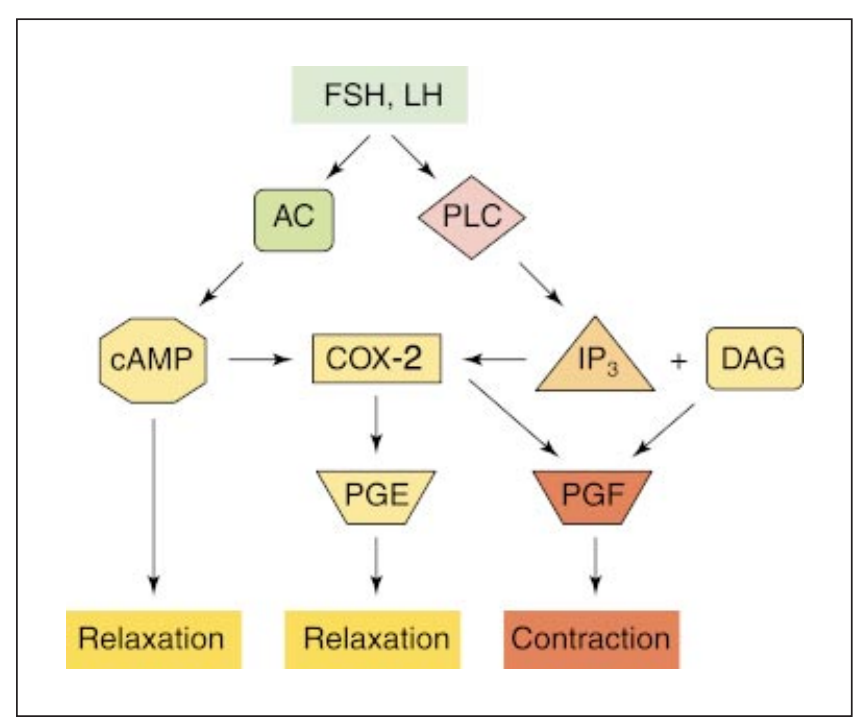

Fig. 4. Putative model for the physiological role of $\mathrm{LH}$ and FSH in uterine tract motility. Both $\mathrm{LH}$ and $\mathrm{FSH}$ possess dual regulatory functions: (1) direct activation of adenylate cyclase to produce CAMP and induce relaxation of the uterine musculature and (2) stimulation of cyclooxygenase (COX)-2 to increase the production of PGE to relax, or PGF to contract, the uterine musculature. AC: adenylate cyclase; DAG: diacylglycerol; $\mathrm{IP}_{3}$ : inositol triphosphate; PLC: phospholipase C.

\section{Uterine vein: physiological role of $L H$ receptor}

The production of $\mathrm{PGI}_{2}$ and $\mathrm{PGF}_{2 \alpha}$ in human uterine vessels may be related to the action of $\mathrm{PGI}_{2}$ on dilating and $\mathrm{PGE}_{2}$ action in constricting uterine vessels in women (Hollister et al., 1988) and dogs (Kimura et al., 1992). Therefore, the differential release of these compounds may be related to vasodilatory effects of $\mathrm{LH}$ on uterine vessels. Increased ovarian blood flow induced by $\mathrm{LH}$ has been demonstrated in women, rabbits and rats, and was one of the earliest reported effects of LH (for references, see Shemesh et al., 1997).

In the uterine vein of cows, an increase in eicosanoids during pro-oestrus-oestrus may play a role in luteolysis by two mechanisms: (1) increasing blood flow in the countercurrent plexus between the uterine artery and ovarian vein by PGE; and (2) increasing the amount of the luteolytic agent (PGF) reaching the corpus luteum. Other roles for uterine venous PGE could be the softening of the cervix at oestrus, initiation of the preovulatory development of antral follicles and the increase in oestradiol secretion from the preovulatory follicles. This hypothesis is supported by the finding of a secondary $\mathrm{LH}$ peak value at the time of luteolysis in goats (Mori and Kano, 1984).

\section{Oviduct: expression of $\mathrm{LH}$ receptor and activity of $\mathrm{LH}$}

$\mathrm{LH} / \mathrm{hCG}$ receptors are present in the human Fallopian tube (Han et al., 1996) and pig oviduct (Gawronska et al., 1999, 2000a). The human Fallopian tube contains LH receptor mRNA transcript and immunoreactive protein. In situ hybridization and immunocytochemistry revealed that tubal LH receptors are present not only in the mucosal cells but also in the smooth muscle and blood vessels. Bovine epithelial cells also contain LH receptors (Sun et al., 1997).

\section{Oviduct: physiological role of $L H$ receptor}

The presence of LH-R in pig oviduct and changes in receptor quantity depending on the hormonal status of animals indicate that $\mathrm{LH}$ directly regulates tubal function. Studies of tissues collected from cyclic gilts revealed that $\mathrm{LH}$ caused relaxation of the oviduct, especially during the periovulatory stage of the oestrous cycle (Gawronska et al., 1999). Treatment with $\mathrm{LH}$ in vitro during the periovulatory stage of the oestrous cycle decreased the amplitude, frequency and area under curve (AUC) of the contraction of the isthmus and the frequency and AUC of ampullar contractions. The frequency and AUC of the oviductal 


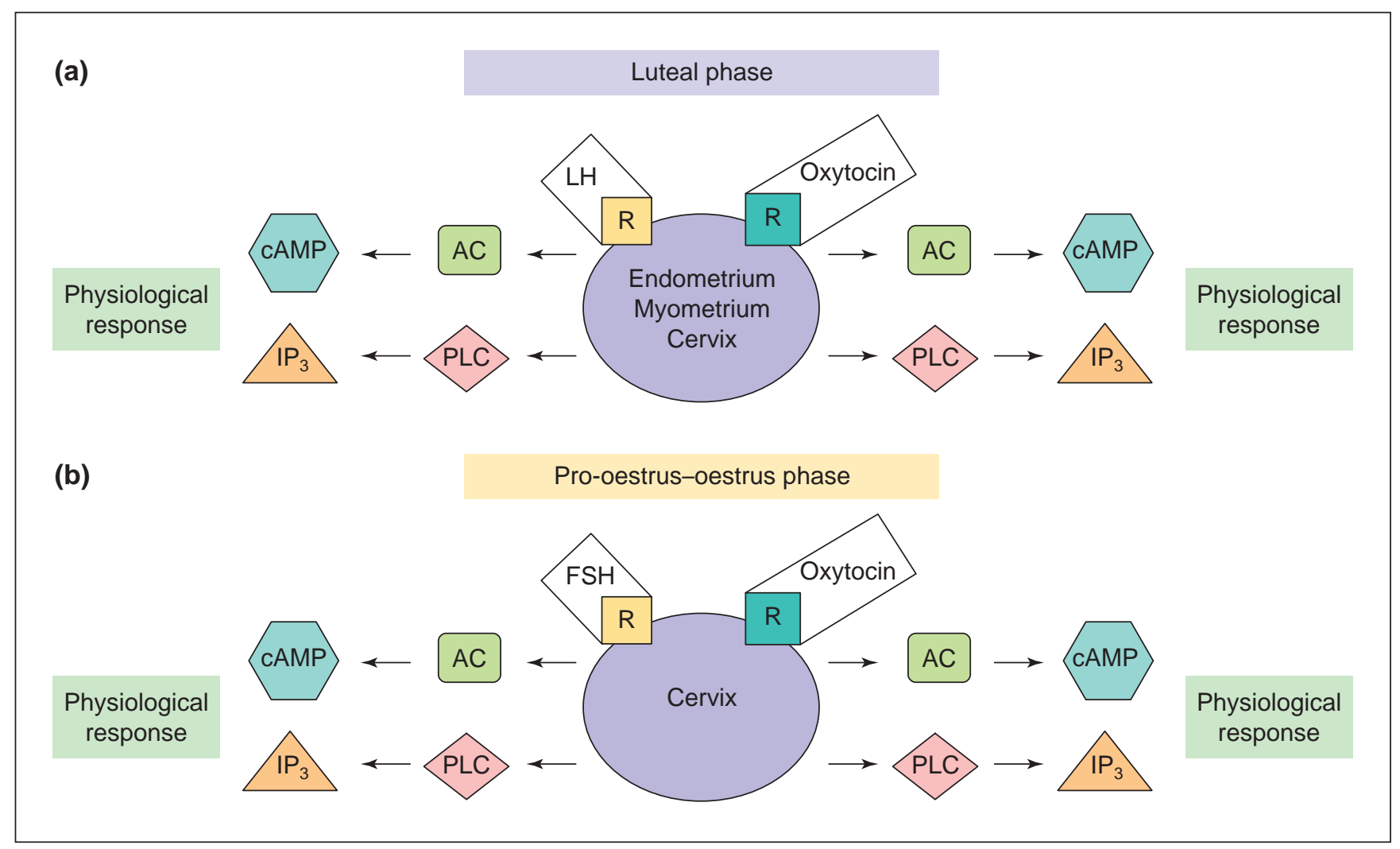

Fig. 5. Schematic presentation of rapid intracellular responses to hormones in uterine cells. CAMP and inositol triphosphate $\left(\mathrm{IP}_{3}\right)$ were measured in uterine tissues in response to $\mathrm{LH}(\mathrm{a}), \mathrm{FSH}(\mathrm{b})$ or oxytocin $(\mathrm{a}, \mathrm{b})$. The uterine cells were most responsive to $\mathrm{LH}$ at the luteal phase but were most responsive to FSH at pro-oestrus-oestrus. Oxytocin was active in both the luteal and pro-oestrous-oestrus phases. AC: adenylate cyclase; PLC: phospholipase C.

contractions were also significantly reduced during the early follicular phase of the oestrous cycle. There was no effect of LH on the frequency and AUC of the spontaneous motility of the oviduct during the luteal stage of the oestrous cycle.

A relaxing effect of hCG on uterine motility was observed in women (Eta et al., 1994). The effect of LH on the spontaneous contractions of the pig oviduct could be detected as early as $10 \mathrm{~min}$ after addition of LH (Gawronska et al., 1999, 2000a). Although the mechanism of the effect of $\mathrm{LH}$ on the oviduct is not clear, it is possible that it acts through locally released factors such as PG, cAMP or nitric oxide. In the human Fallopian tube, Han et al. (1996) showed that $\mathrm{LH}$ treatment increased synthesis of both COX and PGE.

Gawronska et al. (2000b) has suggested that LH should be added to the list of factors affecting oviduct function and that the preovulatory surge of $\mathrm{LH}$, in addition to its role in the induction of ovulation and luteinization of granulosa and theca cells, also plays an important role in controlling oviductal motility and the opening of the ampullar-isthmic junction for spermatozoa. Thus, LH may be a major factor in the synchronization of the events leading to the fertilization of ova in the ampulla. The relaxative action of
LH may also facilitate the passage of embryos through the isthmus towards the uterus.

\section{Cervix: expression of $L H$ receptor and activity of $L H$}

Both $\mathrm{LH}$ and $\mathrm{FSH}$ receptors are present in the bovine cervix (Mizrachi and Shemesh, 1999a,b). During the luteal phase, the bovine external cervix has maximum concentrations of $\mathrm{LH}-\mathrm{R}$ protein and its corresponding mRNA. In contrast, FSH-R protein and its mRNA are expressed maximally in the external cervix at pro-oestrus-oestrus (Fig. 1).

Activation of the $\mathrm{LH}$ receptor or FSH receptor is associated with the G-protein-coupled receptor family that mediates the CAMP and IP signalling pathways. These signalling pathways then increase the expression of cyclooxygenase and the production of $\mathrm{PGE}_{2}$ (Fig. 3).

\section{Cervix: physiological role of $L H$ receptor}

The relaxation and opening of the gravid cervix is due to active biochemical and structural changes in the cervical connective tissue and is mediated in part by prostaglandins (Fuchs et al., 1984). Stretching of the cervix is thought to be a factor in causing the release of these prostaglandins. PGE causes cervical softening in ewes (for references, see 


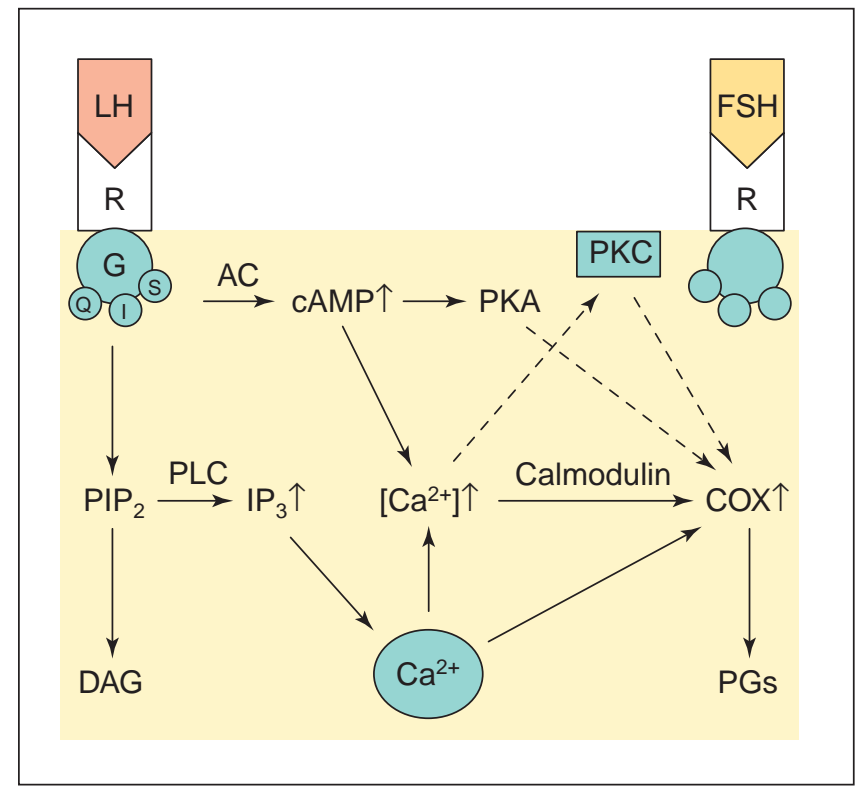

Fig. 6. Putative pathway of gonadotrophin stimulation of uterine prostaglandins. LH and FSH bind to their receptors (R) and, acting through G-protein $(\mathrm{G})$, activate both adenylate cyclase (AC) and phospholipase C (PLC) pathways. In our putative model, gonadotrophin receptor is coupled to $\mathrm{Gi}$ or $\mathrm{Gq}$ proteins, or both, to activate PLC and Gs to activate AC. Products of both the AC and PLC pathways mobilize $\mathrm{Ca}^{2+}$ from intracellular stores in the endoplasmic reticulum. Activation of protein kinase $C$ (PKC) by $\mathrm{Ca}^{2+}$ and diacylglycerol (DAG), activation of protein kinase $\mathrm{A}$ (PKA) by cAMP and activation of calmodulin by $\mathrm{Ca}^{2+}$ then act, independently or synergically, to promote an increase in cyclooxygenase (COX)-2.

Mizrachi and Shemesh, 1999a) and, in both non-pregnant and pregnant cows, $\mathrm{PGE}_{2}$ causes an increase in cervical opening within $3 \mathrm{~h}$ of treatment (Duchens et al., 1993). $\mathrm{PGE}_{1}$ administered to cows intracervically in a jelly was shown to decrease cervical resistance within $24 \mathrm{~h}$ (Graddy et al., 1998).

\section{Actions of the gonadotrophins on the uterine musculature}

A summary of the physiological roles of the gonadotrophins in causing relaxation or contraction of the uterine musculature is shown (Fig. 4). It is proposed that activation of adenylate cyclase is associated with relaxation whereas activation of COX-2 can lead to either a release of PGE, which can relax the muscles, or of PGF, which may contract them.

\section{Action of gonadotrophins on activation of adenylate cyclase and phospholipase $C$}

During the luteal phase, LH induces a rapid increase in endometrial, myometrial and cervical cAMP production.
Similarly, $\mathbb{I P}_{1}, \mathrm{IP}_{2}$ and $\mathrm{IP}_{3}$ are increased by $\mathrm{LH}$ (Fig. 5a) (Mizrachi and Shemesh, 1999a; Shemesh et al., 2001). Uterine tract tissues from other stages of the cycle had only a weak or no response to $\mathrm{LH}$. The refractoriness to $\mathrm{LH}$ during pro-oestrus and oestrus corresponds to the reduced amounts of $\mathrm{LH}-\mathrm{R}$ present in the uterine tract. However, FSH does stimulate production of cAMP and IPs by the cervix (Mizrachi and Shemesh, 1999b) (Fig. 5b). In contrast to FSH and $\mathrm{LH}$, oxytocin increases uterine production of cAMP and IPs at both the luteal and pro-oestrous-oestrous phases (Fig. $5 \mathrm{a}, \mathrm{b})$. Activation of phospholipase C (PLC) and adenylate cyclase (AC) signalling pathways by hCG has also been reported for the pig myometrium (Kisielewska et al., 1996). Therefore, FSH-R and LH-R in the uterus are associated with the same transduction pathways as in the ovary and testes, as reported by Marsh (1975) for CAMP and Davis (1987) for phosphatidyl-ionositol.

The activation of $\mathrm{AC}$ and PLC after binding of $\mathrm{LH}$ or FSH results from stimulation of $G$ protein present in the membrane. Gonadotrophic receptors interact primarily with Gs and to a variable extent with Gq and Gi (Dufau, 1998). Activation of PLC is the initial step of the phosphoinositide cascade that generates the second messengers diacylglycerol (DAG) and inositol triphosphate $\left(\mathrm{IP}_{3}\right)$. Binding of $\mathrm{IP}_{3}$ to receptors in the endoplasmic reticulum stimulates the release of free $\mathrm{Ca}^{2+}$ from the calcium pool of this organelle, which increases the intracellular concentration of $\mathrm{Ca}^{2+}$. The increased amounts of free $\mathrm{Ca}^{2+}$ can bind to regulatory proteins such as calmodulin (Berridge, 1993). $\mathrm{Ca}^{2+}$-bound calmodulin can interact with many enzymes and may enhance or suppress their activity, for example, COX-2 and production of PG. Increasing $\mathrm{Ca}^{2+}$ in concert with DAG is also essential for activating protein kinase $\mathrm{C}$ to promote PGs (Fig. 6).

\section{Is oxytocin the sole luteolytic agent in ruminants?}

It is widely believed that PGF released from the uterus is under the control of oxytocin originating from the corpus luteum. Therefore, it would be expected that pulses of oxytocin from the corpus luteum would increase prostaglandin pulses from the uterus and that the pulses would reinforce each other until luteolysis takes place. However, evidence has accumulated more recently that, at best, oxytocin plays only a secondary role in bovine corpus luteum regression (Hansel and Blair, 1996). On the basis of microdialysis in vivo, luteal regression was found to occur in normal cattle in the absence of the release of measurable amounts of oxytocin from luteal cells. Conversely, luteolysis can fail to occur in animals in which oxytocin release is manifest. Additional experiments, which do not support the oxytocin hypothesis of luteolysis, have been summarized by Hansel and Blair (1996).

The present review describes the novel observations that gonadotrophins are involved in the regulation of uterine COX-2 and its products. The actions of these gonadotrophins were evident throughout the oestrous cycle and 
have been demonstrated in at least three species (cattle, pigs and humans). Therefore it is hypothesized that uterine production of prostaglandin is under the control of several factors including the gonadotrophins and oxytocin. It may well be that no single factor is responsible for release of prostaglandins and that synergetic effects are necessary for sufficient quantities of PGF to cause complete luteolysis.

\section{Conclusions}

The demonstration that FSH-R, GnRH and LH-R are expressed in extragonadal-pituitary tissues does not necessarily mean that they have a physiological function. However, the dynamic pattern of receptor expression in the uterus of several species coupled with the evidence that these receptors are associated with activation of cAMP and IP signalling pathways, indicates that gonadotrophins and GnRH play a substantial role in the molecular autocrineparacrine regulation of the oestrous cycle and embryoendometrial interaction during early implantation.

\section{References}

Key references are identified by asterisks.

Behrman HR (1979) Prostaglandins in hypothalamo-pituitary and ovarian function Annual Reviews of Physiology 41 685-700

Berridge MJ (1993) Inositol triphosphate and calcium signaling Nature 361 315-325

Bonnamy PJ, Benhaim A and Leymarie P (1989) Human chorionic gonadotropin affects tissue levels of progesterone and cyclic adenosine $3^{\prime}-5^{\prime}$-monophosphate in the metestrus rat uterus in vitro. Biology of Reproduction 40 511-516

Bonnamy PJ, Benhaim A and Leymarie P (1990) Estrous cycle related change of high affinity luteinizing hormone/human chorionic gonadotropin binding sites in the rat uterus Endocrinology 126 1264-1269

Canino CJ, Reed J, Shemesh M, Chang SMT, Marion VK, Hiers EA, Binta H, Luce BR, Thatcher WW and Fields MJ (1999) Induction of prostaglandin synthesis via $\mathrm{LH} / \mathrm{hCG}$ receptors in the bovine uterus Biology of Reproduction $\mathbf{6 0}$ Supplement 1262

Catt K and Dufau ML (1991) Gonadotropic hormones: biosynthesis secretion, receptors and actions. In Reproductive Endocrinology pp 105-155 Eds SSC Yen and RB Jeffe. Sounders, Philadelphia

Csapo Al, Pulkkinen MO, Ruttner B, Savauge JP and Wiest WG (1972) The significance of the human corpus luteum in pregnancy maintenance I. Preliminary studies American Journal of Obstetrics and Gynecology 112 1061-1067

Danet-Desmoyers G, Wetzels C and Thatcher WW (1994) Natural and recombinant bovine interferon $\tau$ regulate basal and oxytocin-induced secretion of prostaglandin $F_{2 \alpha}$ and $E_{2}$ by epithelial cells in the endometrium Reproduction, Fertility and Development 7 193-202

Davis JS (1987) Stimulation of intracellular free $\mathrm{Ca}^{2+}$ by luteinizing hormone in isolated bovine luteal cells Advances in Experimental Medicine and Biology 219 671-675

Duchens M, Fredriksson G, Kindahl H and Aiumlamai S (1993) Effect of intracervical administration of a prostaglandin $\mathrm{E}_{2}$ gel in pregnant and non-pregnant heifers Veterinary Record 133 546-549

Dufau ML (1998) The luteinizing hormone receptor Annual Reviews of Physiology 60 461-496

Eta E, Ambrus G and Rao CV (1994) Direct regulation of human myometrial contractions by human chorionic gonadotropin Journal of Clinical Endocrinology and Metabolism 79 1582-1586

Flowers B, Ziecik AJ and Caruolo EV (1991) Effects of human chorionic gonadotropin on contractile activity of steroid-primed pig myometrium in vitro. Journal of Reproduction and Fertility 92 425-432
Freidman S, Gurevich M and Shemesh M (1995) Bovine cyclic endometrium contains high affinity luteinizing hormone/human chorionic gonadotropin binding sites Biology of Reproduction $\mathbf{5 2}$ 1020-1026

Fuchs A-R, Goeschen J, Rasmussen AB and Rehnström JV (1984) Cervical ripening by endocervical and extra-amniotic PGE $_{2}$ Prostaglandins 28 $217-227$

*Gawronska B, Paukku T, Huhtaniemi I, Wasowicz G and Ziecik AJ (1999) Oestrogen-dependent expression of LH/ hCG receptors in pig Fallopian tube and their role in relaxation of the oviduct Journal of Reproduction and Fertility 115 293-301

Gawronska B, Stepien A and Ziecik AJ (2000a) Effect of estradiol and progesterone on oviductal $\mathrm{LH}$-receptors and $\mathrm{LH}$-dependent relaxation of the porcine uterus Theriogenology 53 659-672

Gawronska B, Stepien A and Ziecik AJ (2000b) Role of luteinizing hormone in control of oviduct function Reproduction in Domestic Animals 35 129-133

Graddy L, Fields M, Kowalski A, Chang S-M and Fuchs A-R (1998) Effects of oxytocin and $\mathrm{PGE}_{1}$ on bovine cervix at estrus Biology of Reproduction 58 Supplement 1174 (Abstract 327)

Han SW, Lei ZM and Rao ChV (1996) Up-regulation of cyclooxygenase-2 gene expression by chorionic gonadotropin in mucosal cells from human Fallopian tubes Endocrinology 137 2929-2937

Hansel W and Blair RM (1996) The role of lipoxgenase products of arachidonic acid metabolism in bovine corpus luteum function Reproduction in Domestic Animals 31 427-429

Hollister MC, Reid DI, Phaeton TM, Landauer M and Ranken JHG (1988) Dose-response curves of uterine and placental vascular beds to prostaglandins $\mathrm{I}_{2}$ American Journal of Obstetrics and Gynecology 159 1372-1375

Huhtaniemi IT and Catt KJ (1981) Differential binding affinities of rat testis luteinizing hormone ( $\mathrm{LH})$ receptors for human chorionic gonadotropin, human LH, and ovine LH Endocrinology 108 1931-1938

Jensen TD and Odell WD (1988) Identification of LH/hCG receptors in rabbit uterus Proceedings of the Society for Experimental Biology and Medicine 189 28-30

Kimura T, Yoshida Y and Toda N (1992) Mechanisms of relaxation induced by prostaglandins in isolated canine uterine arteries American Journal of Obstetrics and Gynecology 167 1407-1416

Kisielewska J, Flint APF and Ziecik AJ (1996) Phospholipase C and adenylate cyclase signalling systems in the action of hCG on porcine myometrial smooth muscle cells Journal of Endocrinology 148 175-180

Marsh JM (1975) The role of cyclic AMP in gonadal function. In Cyclic Nucleotide Research Vol. 6 pp 137-199 Eds P Greengard and GA Robinson. Raven Press, NY

*Mizrachi D and Shemesh M (1999a) Expression of functional luteinising hormone receptor and its messenger ribonucleic acid in bovine cervix: luteinising hormone augmentation of intracellular CAMP, phosphate inositol and cyclooxygenase Molecular and Cellular Endocrinology 157 191-200

*Mizrachi D and Shemesh M (1999b) Follicular stimulating hormone receptor and its messenger RNA are present in the bovine cervix and can regulate cervical prostanoid synthesis Biology of Reproduction $\mathbf{6 1}$ 776-784

Mori $\mathbf{Y}$ and Kano $\mathbf{Y}$ (1984) Changes in plasma concentrations of $\mathrm{LH}$, progesterone and oestradiol in relation to the occurrence of luteolysis, oestrus and the time of ovulation in the Shiba goat (Capra hircus) Journal of Reproduction and Fertility 72 223-230

Pierce J and Parsons T (1981) Glycoprotein hormones: structure and function Annual Reviews of Biochemistry 50 465-495

*Raga F, Casañ EV, Krussel JS, Wen Y, Huang H-Y, Nezhat C and Polan ML (1998) Quantitative gonadotropin-releasing hormone gene expression and immunohistochemical localization in human endometrium throughout the menstrual cycle Biology of Reproduction 59 661-669

Rahe CH, Owens RE, Fleeger JL, Newton HJ and Harms PG (1980) Pattern of plasma luteinizing hormone in the cyclic cow: dependence upon the period of the cycle Endocrinology 107 498-503

Reshef E, Lei ZM, Rao ChV, Pridham DD, Chegini N and Luborsky JL (1990) The presence of gonadotropin receptors in nonpregnant human uterus, 
human placenta, fetal membranes, and decidua Journal of Clinical Endocrinology and Metabolism 70 421-430

Rodriguez MC and Segaloff DL (1990) The orientation of the lutropin/choriogonadotropin receptor in rat luteal cells as revealed by site-specific antibodies Endocrinology 127 674-681

Rodway MR and Rao ChV (1995) A novel prospective on the role of human chorionic gonadotropin during pregnancy and gestational trophoblastic disease Early Pregnancy: Biology and Medicine 3 176-187

Sawitzke AL and Odell WO (1991) Uterine binding sites for LH/hCG can be modulated by hormonal status in rabbits and rats Acta Endocrinologia (Copenhagen) 124 322-330

Shemesh M, Freidman S, Harel-Markowitz E and Gurevich M (1994) Induction and regulation of the PGHS in the bovine endometrium. In Lipid Mediators in Health and Disease pp 71-78 Ed. M Zor. Freund Publishing House Ltd, Tel Aviv

Shemesh M, Gurevich M, Mizrachi D, Dombrovski L, Stram Y, Fields MJ and Shore LS (1997) Expression of functional luteinizing hormone receptor and its $\mathrm{mRNA}$ in bovine uterine veins; luteinizing hormone induction of PGHS and augmentation of prostaglandin production in bovine uterine veins Endocrinology 138 4844-4851

Shemesh M, Gurevich M, Mizrachi D, Stram Y, Shore LS and Fields MJ (2001) Functional importance of bovine uterine and vascular LH/hCG receptors Seminars in Reproductive Medicine 19 87-96

Stepien A, Shemesh M and Ziecik AJ (1999) Luteinizing hormone receptor kinetic and $\mathrm{LH}$-induced prostaglandin production throughout the oestrous cycle in porcine endometrium Reproduction, Nutrition and Development 39 663-674

Sun T, Lei ZM and Rao ChV (1997) A novel regulation of the oviductal glycoprotein gene expressing by luteinizing hormone in bovine tubal epithelial cells Molecular and Cellular Endocrinology 131 97-108

Thatcher WW, Eley RM, Bazer FW and Fields MJ (1983) Steroid metabolism by the bovine endometrium and conceptus Biology of Reproduction 28 804-816

Weems YS, Vincent DL, Nusser Y, Tanaka K, Miller-Patrick K, Ledgerwood KS and Weems CW (1993) Effects of prostaglandins $F_{2 \alpha}$ on uterine or ovarian secretion of prostaglandins $E$ and $F_{2 \alpha}$ in vivo in 90-100 day hysterectomized, intact or ovariectomized pregnant ewes Prostaglandin 46 277-296

Ziecik AJ, Stanchev PD and Tilton JE (1986) Evidence for the presence of luteinizing hormone/human chorionic gonadotropin-binding sites in the porcine uterus Endocrinology 119 1159-1163

Ziecik AJ, Derecka-Reszka KA and Rzucidlo SJ (1992a) Extragonadal gonadotropin receptors, their distribution and function Journal of Physiology and Pharmacology 43 Supplement $133-49$

*Ziecik AJ, Jedlinska M and Rzucidlo JS (1992b) Effect of estradiol and progesterone on myometrial $\mathrm{LH} / \mathrm{hCG}$ receptors in pigs Acta Endocrinologia 127 185-188

Ziecik AJ, Stepien A and Gawronska B (2000) Importance of endometrial luteinizing hormone receptors in induction of luteolysis and maternal recognition of pregnancy in the pig Reproduction in Domestic Animals 35 190-192 